\title{
PENERAPAN MODEL PEMBELAJARAN CONCEPT ATTAINMENT UNTUK MENINGKATKAN AKTIVITAS MATEMATIKA SISWA SMP
}

\author{
Fransisca Theresia Sijabat ${ }^{1}$, Effie Efrida Muchlis, Nurul Astuty Yensy B. ${ }^{3}$ \\ Program Studi Pendidikan Matematika, JPMIPA, FKIP Universitas Bengkulu \\ email :1 fransisca035@gmail.com, ${ }^{2}$ effie_efrida@unib.ac.id, ${ }^{3}$ nurulastutyyensi@yahoo.com
}

\begin{abstract}
Abstrak
Penelitian ini bertujuan untuk mengetahui cara penerapan model pembelajaran concept attainment sehingga dapat meningkatkan aktivitas belajar matematika siswa kelas VII SMP Negeri 1 Pondok Kelapa. Jenis penelitian yang dilaksanakan adalah Penelitian Tindakan Kelas (PTK) dengan teknik pengumpulan data melalui lembar observasi aktivitas siswa. Subjek dalam penelitian ini adalah siswa kelas VII 2 SMP Negeri 1 Pondok Kelapa tahun ajaran 2017/2018 yang berjumlah 28 orang. Hasil penelitian ini menunjukkan penerapan model pembelajaran concept attainment dapat meningkatkan aktivitas belajar siswa. Peningkatan aktivitas dapat dilihat dari skor rata-rata observasi siswa siklus I, II, dan III secara berturut-turut yaitu 27,875 (cukup aktif); 36,75 (aktif); dan 43,75 (sangat aktif).

Kata kunci: aktivitas belajar, model pembelajaran concept attainment.
\end{abstract}

\begin{abstract}
The aim of this research was to know how to implement concept attainment learning model in order to improve student's activity of grade VII class at Junior High School Number 1 Pondok Kelapa. The type of research was Classroom Action Research (CAR) with collecting data technique by using observation sheet of student's activity. The Subject in this research was 28 students of class VII 2 Junior High School 1 Pondok Kelapa even semester of academic year 2017/2018. Amount of the subject in this research was 28 students. This research showed that the implementation of concept attainment learning model can improve student's activity. The activity improvement can be seen from mean scores of student's observation on first, second and third cycle respectively which were 27,875; 36,75; and 43,75 with their criteria that include quite active, active, and very active.
\end{abstract}

Key terms: learning activity, concept attainment learning models

\section{PENDAHULUAN}

Matematika merupakan salah satu mata pelajaran yang memiliki peranan penting dalam pendidikan. Hal ini dapat dilihat dari waktu jam pelajaran di sekolah lebih banyak dibandingkan dengan pelajaran lain. Dalam proses pembelajaran, guru matematika sebaiknya memahami cara untuk memberikan rangsangan pada siswa sehingga siswa dapat memahami konsep dasar dari materi yang disampaikan. Hal ini sesuai dengan Peraturan Menteri Pendidikan Nasional (Permendiknas) Republik Indonesia Nomor 20 Tahun 2006 tentang Standar Isi untuk Satuan Pendidikan Dasar dan Menengah yang menyebutkan tujuan pertama mata pelajaran matematika adalah peserta didik memiliki kemampuan memahami konsep matematika, menjelaskan keterkaitan antar konsep dan mengaplikasikan konsep atau algoritma, secara luwes, akurat, efisien, dan tepat, dalam pemecahan masalah.

Pada pembelajaran matematika perolehan konsep merupakan hal yang penting. Menurut Dahar (2011: 63) konsep merupakan abstraksi mental yang mewakili satu kelas stimulus. Konsep dapat diperoleh dengan menyusun ide yang penting dari ide yang umum. Konsep dikatakan telah dipelajari apabila konsep telah diterapkan seorang yang mempelajari konsep tersebut dalam kehidupannya. Konsep dapat membantu seseorang dalam menjelaskan, menganalisis, dan menghubungkan suatu materi yang dipelajari di sekolah. 
Dengan memperoleh konsep matematika siswa dapat mengerti tentang definisi, cara pemecahan masalah, maupun pengoprasian materi matematika secara benar. Namun kenyataan saat ini penguasaan dan pemahaman siswa terhadap konsep matematika masih lemah. Hal ini dikarenakan proses pembelajaran yang kurang mendalam dan kurang menekankan konsep matematika tersebut. Materi matematika yang diterima siswa secara pasif menjadikan matematika kurang bermakna bagi siswa. Siswa pun menjadi kurang aktif dalam proses pembelajaran dikarenakan pembelajaran yang monoton dan kurangnya penekanan konsep.

Pelibatan seluruh siswa untuk dapat aktif dalam proses pembelajaran sangat diperlukan. Keaktifan peserta didik dalam menjalani proses belajar mengajar merupakan salah satu kunci keberhasilan pencapaian tujuan pendidikan. Menurut Sardiman (2008: 97) jika tidak ada aktivitas, maka proses pembelajaran tidak dapat berjalan dengan dengan baik. Aktivitas siswa selama pembelajaran mencerminkan adanya motivasi ataupun keinginan siswa untuk belajar.

Aktivitas siswa tidak cukup hanya mendengarkan dan mencatat seperti yang biasa terjadi di beberapa sekolah. Hal ini terjadi karena guru sering menggunakan metode konvensional atau ceramah pada proses pembelajaran. Maka harus adanya serangkaian kegiatan yang dilakukan siswa dalam proses pembelajaran agar mencapai tujuan pembelajaran sesuai indikator aktivitas belajar.

Dengan adanya masalah ini, maka perlu diterapkannya suatu model pembelajaran yang dapat melibatkan siswa aktif dalam membangun ide, konsep, prinsip, dan struktur matematika berdasarkan pengalamannya sendiri. Dengan kata lain siswa dapat memperoleh konsep sendiri dari contoh yang benar dan yang tidak benar. Pemahaman konsep ini akan membantu siswa untuk memahami materi selanjutnya. Salah satu model pembelajaran yang dapat diterapkan adalah concept attainment.
Concept attainment dalam bahasa Indonesia dapat diartikan pencapaian atau perolehan konsep. Concept attainment menuntut siswa mampu menjelaskan ide-ide untuk menemukan suatu konsep matematika.Jika siswa sudah mampu menjelaskan ide-ide tersebut, maka siswa mampu membedakan hal-hal yang sesuai dengan konsep dan yang tidak sesuai dengan konsep.Selanjutnya siswa akan mampu memahami dan menyimpulkan suatu konsep matematika secara mandiri dengan bimbingan guru. Dengan demikian siswa akan lebih memahami konsep tersebut karena ia sendiri yang memperolehnya.

Model concept attainment adalah model yang menerapkan proses mencari dan mendaftar sifat-sifat yang dapat digunakan untuk membedakan contoh yang tepat dan yang tidak tepat (Huda, 2017: 81). Dari penjelasan ini maka dapat terlihat aktivitas siswa untuk memperoleh sebuah konsep melalui contoh dan bukan contoh. Berdasarkan pengamatan siswa tentang contoh dan bukan contoh tersebut maka diharapkan siswa dapat menyebutkan pendapatnya mengenai konsep yang ia peroleh. Tugas guru pada proses pembelajaran adalah menuntun siswa agar dapat mengkonstruksikan konsep dengan sesuai.

Menurut Uno (2017: 10) model pembelajaran perolehan konsep adalah suatu model pembelajaran yang bertujuan membantu siswa untuk memahami suatu konsep pelajaran. Pemahaman siswa pada suatu konsep pembelajaran ini akan mempermudah siswa untuk memahami konsep dari pelajaran lebih tinggi. Perolehan konsep pada siswa ini berguna agar siswa dapat mengkategorikan suatu materi pembelajaran. Dengan memperoleh konsep, siswa juga dapat menemukan hal-hal baru yang dapat ia kembangkan dalam kesehariannya.

Model pembelajaran concept attainment memiliki tiga tahapan dalam proses pembelajarannya. Uno (2017: 11) menyatakan tahap pertama pada model ini adalah tahap kategorisasi, yaitu upaya mengkategorikan yang sesuai atau tidak dengan konsep yang 
diperoleh.Selanjutnya adalah tahap menyesuaikan kategori yang sesuai dan yang tidak sesuai di singkirkan, kategori yang sudah sesuai digabungkan agar membentuk suatu konsep.Tahap terakhir adalah menyimpulkan dari hasil pada tahap kedua, maka siswa dapat memperoleh suatu konsep.

Joyce, Weil, dan Calhoun (2009: 136) menjelaskan pula ada tiga tahapan yang dapat dilakukan agar siswa dapat mencapai suatu konsep dengan model pembelajaran concept attainment. Pada tahap awal akan diberikan lembar pembelajaran yang berisi unit yang merupakan contoh dan noncontoh. Selanjutnya, siswa menguji penemuan yang telah ia lakukan. Pengujian ini dilakukan dengan cara mengidentifikasikan secara tepat contoh-contoh yang tidak diberi penjelasan yang merupakan contoh yang tepat dan contoh yang tidak tepat, pada tahap ini juga ditambah dengan contoh yang siswa sendiri berikan. Tahap terakhir adalah tempat siswa menganalisis dari ide yang ia terima di tahap-tahap sebelumnya. Dari kesimpulan analisis siswa inilah akan diperoleh suatu konsep.

Secara Ringkas, berikut tahapan Model Pembelajaran Concept Attainment.menurut Joyce, Weil, dan Calhoun (2009: 136)

\section{Tahap Pertama:}

\section{Penyajian Data dan Identifikasi Konsep}

1. Guru menyajikan contoh-contoh yang telah dilabeli.

2. Siswa membandingkan sifat atau ciri dalam contoh positif dan contoh negatif.

Siswa menjelaskan definisi menurut sifat atau ciri yang paling mendasar.

\section{Tahap Kedua:}

\section{Pengujian Pencapaian Konsep}

1. Siswa mengidentifikasi contoh tambahan yang tidak dilabeli dengan tanda $\mathrm{Ya}$ atau Tidak.

2. Guru menguji hipotesis, menamai konsep, dan menyatakan kembali definisi dan sifat yang mendasar.

3. Siswa membuat contoh-contoh.

\section{Tahap Ketiga:}

\section{Analisis Strategi-Strategi Berpikir}

1. Siswa mendeskripsikan pemikiranpemikiran.

2. Siswa mendiskusikan peran sifat dan hipotesis.

3. Siswa mendiskusikan jenis dan ragam hipotesis.

Model pembelajaran concept attainment memiliki kelebihan yang dapat memperbaiki masalah dalam pembelajaran (Ridwan, 2013: 12). Dalam model ini siswa akan mempunyai gambaran umum tentang konsep materi pembelajaran, dengan demikian pembelajaran ini akan lebih aktif karena adanya pertanyaanpertanyaan siswa untuk memastikan apakah gambaran umum yang dimilikinya sesuai dengan konsep materi yang diajarkan. Siswa juga dapat mengukur kemampuannya dalam pencapaian konsep dengan mengoreksi hasil pemikirannya dengan konsep matematika yang ada. Kemungkinan alasan siswa untuk lupa akan konsep juga dapat diperkecil, karena pada model ini siswa bukan menghafal melainkan menemukan konsep dari hasil pemikirannya sendiri berdasarkan ide-ide yang diberikan guru. Selain kelebihan yang telah dijelaskan, Ridwan (2013: 13) menjelaskan bahwa model concept attainment memiliki kekurangan jika guru tidak terampil dalam mempersiapkan maupun dalam proses pembelajaran di dalam kelas.

Model pencapaian konsep ini dapat diterapkan di segala tingkatan pendidikan. Hanya saja untuk tingkatan anak usia dini, tahap analisis berpikir kurang sesuai untuk diterapkan. Tahapan ini cocok diterapkan mulai dari jenjang pendidikan Sekolah Dasar (SD) tingkat tinggi (kelas 4, 5, dan 6). Dengan kegiatan ini akan mudah melihat respon dan aktivitas siswa. Inti yang harus diterapkan pada model ini bukanlah menemukan atau konsepkonsep baru melainkan mencapai konsep yang sebelumnya telah dipilih oleh guru (Huda, 2017: 83).

Tujuan penelitian ini adalah untuk meningkatkan aktivitas belajar siswa kelas VII 
SMP Negeri 1 Pondok Kelapa melalui penerapan model pembelajaran concept attainment.

\section{METODE}

Jenis penelitian yang digunakan adalah Penelitian Tindakan Kelas (Classroom Action Research).Menurut Hamdani (2011: 326) Penelitian Tindakan Kelas adalah kegiatan ilmiah yang mampu merefleksikan kegiatan pembelajaran di kelas melalui penelitian ilmiah yang dapat dipertanggungjawabkan dengan prosedur dan persyaratan yang ada. Tindakan tersebut diberikan oleh guru dengan arahan guru yang dilakukan oleh siswa tanpa mengurangi perhatian terhadap kelas dan prestasi siswa. Tindakan ini juga biasanya berupa tindakan untuk memperbaiki sesuatu yang salah dalam pembelajaran sebelumnya. Menurut Trianto (2011: 36) tahapan pada setiap siklus meliputi perencanaan tindakan (planning), pelaksanaan tindakan (acting), pengamatan terhadap tindakan (observing), dan refleksi terhadap tindakan (reflecting).

Subjek penelitian ini adalah siswa kelas VII 2 SMP Negeri 1 Pondok Kelapa tahun ajaran 2017/2018 yang berjumlah 28 siswa, yaitu 15 siswa laki-laki dan 13 siswa perempuan.

Teknik pengumpulan data yang digunakan dalam penelitian ini adalah dengan menggunakan data langsung tentang aktivitas belajar siswa.Aktivitas belajar siswa didapat dari hasil pengamatan oleh dua orang pengamat, yaitu guru matematika dan teman sejawat.

Berikut adalah tabel kriteria penelitian untuk observasi aktivitas siswa.

Tabel 1. Kriteria Penelitian untuk Observasi Aktivitas Siswa

\begin{tabular}{|c|c|c|}
\hline $\begin{array}{c}\text { Kriteria } \\
\text { Penelitian }\end{array}$ & Notasi & Skor \\
\hline Kurang Aktif & K & 1 \\
\hline Cukup Aktif & C & 2 \\
\hline Aktif & B & 3 \\
\hline Sangat Aktif & S & 4 \\
\hline
\end{tabular}

Sumber: Adaptasi dari Sudjana (2016: 77)
Lembar observasi aktivitas siswa berjumlah 12 butir observasi, skor tertinggi tiap butir adalah 3 , maka skor tertinggi adalah $4 \mathrm{x}$ $12=48$. Sedangkan skor terendah tiap butir adalah 1 , maka skor terendah adalah $1 \times 12=$ 12. Diperoleh kisaran untuk tiap kriteria adalah sebagai berikut.

$$
\begin{gathered}
\text { Kriteria nilai tiap aspek }=\frac{(48-12)+1}{4} \\
\text { Kriteria nilai tiap aspek }=\frac{37}{4}=9,25
\end{gathered}
$$

Aktivitas belajar siswa diamati oleh dua orang pengamat, sehingga untuk menganalisis skor pada hasil observasi aktivitas siswa dapat ditemukan dengan cara sebagai berikut.

$$
\text { nilai skor }(x)=\frac{P 1+P 2}{2}
$$

Sumber: Adaptasi dari Sudjana (2016: 109)

Keterangan:

$x=$ nilai skor aktivitas siswa

$P 1=$ jumlah skor aktivitas yang diamati oleh pengamat 1

$P 2=$ jumlah skor aktivitas yang diamati oleh pengamat 2

Setelah diperoleh nilai skor siswa, maka kisaran skor penilaian untuk lembar observasi aktivitas siswa adalah sebagai berikut.

\section{Tabel 2. Kisaran Skor Lembar Observasi} Aktivitas Siswa

\begin{tabular}{|c|c|c|}
\hline $\begin{array}{c}\text { Kriteria } \\
\text { Penelitian }\end{array}$ & Notasi & Kisaran Skor \\
\hline Kurang Aktif & K & $12 \leq x<21,25$ \\
\hline Cukup Aktif & C & $21,25 \leq x<30,5$ \\
\hline Aktif & B & $30,5 \leq x<39,75$ \\
\hline Sangat Aktif & S & $39,75 \leq x \leq 48$ \\
\hline
\end{tabular}

Keterangan:

$x=$ nilai skor aktivitas siswa

Kisaran skor untuk perhitungan atau analisis aktivitas per aspek juga ditentukan berdasarkan rumus pembagian interval sebagai berikut. 


$$
\text { interval }=\frac{4-1}{4}=\frac{3}{4}=0,75
$$

Jadi interval skor untuk aktivitas siswa pada setiap aspeknya adalah 0,75. Kriteria penilaian untuk menganalisis aktivitas pada setiap aspeknya dapat dilihat berdasarkan kisaran skor seperti berikut.

Tabel 3. Kriteria Penilaian untuk Observasi Aktivitas Siswa pada Setiap Aspek

\begin{tabular}{|c|c|}
\hline $\begin{array}{c}\text { Kisaran Skor Aktivitas } \\
\text { Siswa pada Setiap Aspek }\end{array}$ & Kriteria \\
\hline $1,00 \leq x_{i}<1,75$ & Kurang Aktif (K) \\
\hline $1,75 \leq x_{i}<2,5$ & Cukup Aktif (C) \\
\hline $2,5 \leq x_{i}<3,25$ & Aktif (B) \\
\hline $3,25 \leq x_{i} \leq 4,00$ & Sangat Aktif (S) \\
\hline
\end{tabular}

Keterangan: $x_{i}=$ skor aktivitas siswa aspek ke-i

Indikator keberhasilan tindakan ini adalah aktivitas belajar siswa dalam pelaksanaan pembelajaran minimal berada pada kriteria sangat aktif yaitu memenuhi interval 39,75 $\leq$ $x \leq 48$.

\section{HASIL DAN PEMBAHASAN Hasil}

Penelitian tindakan kelas melalui penerapan model pembelajaran concept attainment di kelas VII 2 SMP Negeri 1 Pondok Kelapa dilaksanakan dari tanggal 27 Maret 2018 sampai dengan 15 Mei 2018. Kegiatan yang dilakukan sebelum melakukan penelitian adalah pengamatan terhadap sasaran penelitian untuk mendapatkan informasi serta refleksi awal mengenai proses pembelajaran pada sasaran penelitian.

Refleksi awal dilakukan sebelum melakukan tindakan pada sasaran penelitian di kelas VII 2 SMP Negeri 1 Pondok Kelapa, yaitu pada tanggal 27 Februari 2018. Penelitian melakukan observasi dan wawancara ini dilakukan dengan Bapak Ramli, S.Pd selaku guru matematika di kelas VII 2 untuk mengetahui proses pembelajaran matematika. Berdasarkan hasil observasi pembelajaran di kelas tersebut, gambaran umum proses pembelajaran matematika di kelas VII 2 SMP
Negeri 1 Pondok Kelapa adalah sebagai berikut.

1. Pembelajaran masih berlangsung satu arah, ini menyebabkan hampir seluruh siswa kurang aktif dalam merespon apa yang disampaikan oleh guru dalam pembelajaran matematika.

2. Kurangnya penekanan akan konsep matematika, ini menyebabkan mayoritas siswa menghafal rumus dan memperbesar kemungkinan siswa lupa akan rumus matematika tersebut.

3. Keheterogenan kemampuan akademis siswa dalam memahami pelajaran beragam. Ini dapat dilihat dari varians nilai akhir ujian semester ganjil siswa yang tinggi yaitu 116,39.

Selanjutnya peneliti melaksanakan kegiatan pembelajaran dengan menerapkan model pembelajaran Concept Attainment untuk meningkatkan aktivitas belajar matematika siswa yang diperoleh dari hasil refleksi awal.

Aktivitas belajar siswa pada penelitian ini diperoleh dari hasil pengamatan dari dua orang pengamat yang dilakukan pada saat berlangsungnya kegiatan belajar mengajar di kelas melalui lembar observasi siswa dengan 12 butir indikator aktivitas siswa. Pengamatan ini bertujuan untuk mengetahui aktivitas siswa pada saat penerapan model pembelajaran concept attainment terhadap kegiatan pembelajaran pada tiap siklus.

Tabel 4. Hasil Pengamatan Aktivitas Siswa

\begin{tabular}{|c|c|c|c|c|c|c|}
\hline \multirow{2}{*}{ Pert. } & \multicolumn{2}{|c|}{ Siklus I } & \multicolumn{2}{|c|}{ Siklus II } & \multicolumn{2}{|c|}{ Siklus III } \\
\hline & P1 & $\mathbf{P 2}$ & P1 & $\mathbf{P 2}$ & P1 & $\mathbf{P 2}$ \\
\hline Pert. 1 & 21 & 26 & 31 & 33 & 38 & 39 \\
\hline Pert. 2 & 29 & 28 & 35 & 37 & 44 & 44 \\
\hline Pert. 3 & 28 & 28 & 37 & 37 & 45 & 46 \\
\hline Pert. 4 & 31 & 32 & 42 & 42 & 47 & 47 \\
\hline $\begin{array}{c}\text { Rata-rata } \\
\text { Pert. }(1,2 \text {, } \\
3,4)\end{array}$ & $\begin{array}{l}27, \\
25\end{array}$ & $\begin{array}{c}28, \\
5\end{array}$ & $\begin{array}{l}36, \\
25\end{array}$ & $\begin{array}{l}37, \\
25\end{array}$ & $\begin{array}{c}43 \\
5\end{array}$ & 44 \\
\hline $\begin{array}{l}\text { Rata-rata } \\
\mathbf{P}(1 \text { dan } 2)\end{array}$ & \multicolumn{2}{|c|}{27,875} & \multicolumn{2}{|c|}{36,75} & \multicolumn{2}{|c|}{43,75} \\
\hline Kriteria & \multicolumn{2}{|c|}{$\begin{array}{c}\text { Cukup } \\
\text { Aktif }\end{array}$} & \multicolumn{2}{|c|}{ Aktif } & \multicolumn{2}{|c|}{$\begin{array}{c}\text { Sangat } \\
\text { Aktif }\end{array}$} \\
\hline
\end{tabular}




\section{Pembahasan}

Pada siklus I, rata-rata aktivitas belajar siswa masih dalam kategori cukup yaitu 27,875 yaitu berada pada rentang $21,25 \leq x<30,5$, dimana $x$ adalah jumlah skor. Dalam kegiatan diskusi siswa, beberapa kelompok sudah melakukan pembagian tugas dengan baik, tetapi masih ada anggota kelompok yang belum mempunyai kesadaran untuk ikut serta dalam kegiatan kelompok. Masih ada anggota kelompok yang hanya melihat dan mengganggu teman dari kelompok yang lain. Hal ini terjadi dikarenakan banyak siswa yang kurang puas atas kelompok yang telah guru bagikan. Untuk itu guru memberikan pengertian kepada siswa atau kelompok yang terima akan kelompoknya tersebut.

Dari hasil observasi siklus II diperoleh rata-rata skor dari dua observer 36,75 dimana berada pada rentang $30,5 \leq x<39,75$ yang berada pada kriteria aktif. Dalam kegiatan diskusi siswa, pembagian tugas pada kelompok sudah baik. Siswa yang ribut dan keluar masuk kelas sudah berkurang. Tetapi masih ada beberapa siswa yang mengganggu temannya yang sedang melakukan kegiatan mengukur dengan meminjam alat ukur dan tidak dikembalikan dengan segera, walaupun telah disediakan oleh guru alat ukur untuk masing-masing kelompok. Keaktifan siswa juga terlihat ketika diminta untuk mempresentasikan hasil diskusi di depan kelas. Sudah terdapat dua kelompok yang mengajukan diri untuk mempresentasikan tugas dibandingkan pada siklus I yang sulit sekali untuk meminta siswa mempresentasikan hasil kegiatannya di depan kelas.

Dari rata-rata skor dari dua observer aktivitas belajar siswa diperoleh 43,75 yang mana berada pada interval $39,75 \leq x \leq 48$ dan terlihat bahwa kriteria keaktifan siswa pada siklus III adalah sangat aktif. Pada siklus III ini, masih ada aspek yang belum berada pada kriteria sangat aktif yaitu aspek bertanya dan memberi tanggapan. Hal ini dikarenakan siswa belum terlalu kritis menyikapi hasil diskusi kelompok lain.
Aktivitas belajar siswa selalu mengalami peningkatan setiap siklusnya. Sedangkan berdasarkan analisis data hasil pengamatan setiap siklus, per indikator, butir penilaian aktivitas perkembangan aktivitas siswa sangat beragam. Keberagaman tersebut dapat dilihat pada grafik berikut.

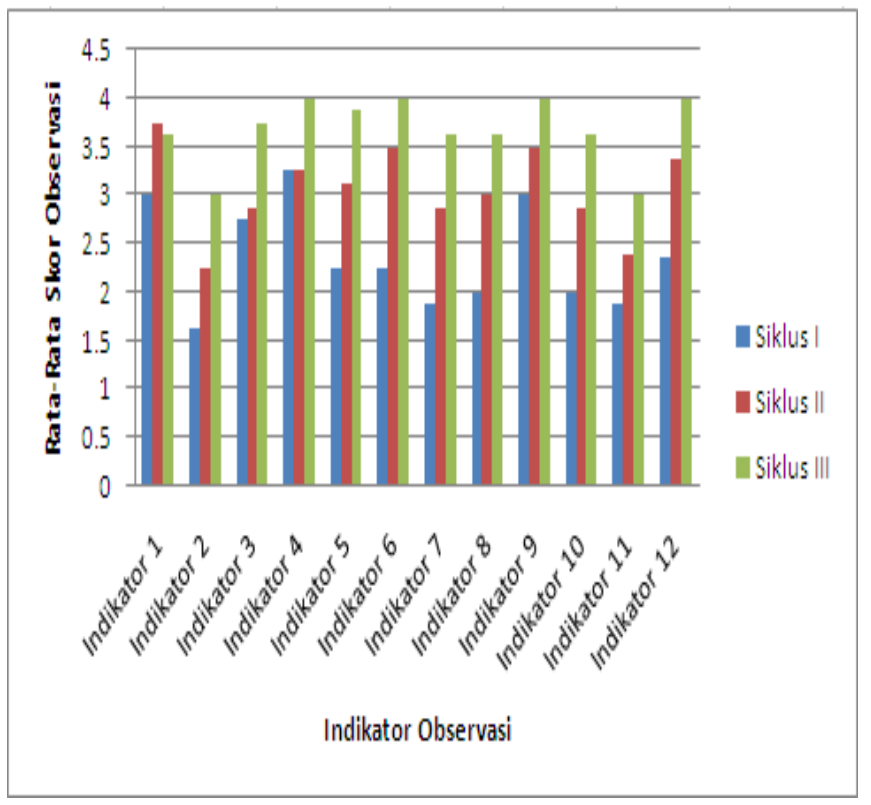

\section{Gambar 1. Grafik perkembangan aktivitas siswa per indikator observasi}

Pada siklus I adalah masih siswa yang kurang mengerti pada proses pembelajaran dan siswa ini merasa takut untuk bertanya kepada guru (indikator 2). Hal ini dikarenakan siswa telah terbiasa dengan pembelajaran yang hanya menerima saja dari guru dan jarang diminta untuk bertanya. Dalam hal ini guru mencoba mendatangi siswa yang terlihat kesulitan saat proses pembelajaran berlangsung dan memotivasi agar bertanya langsung kepada guru jika ada bagian yang belum dipahami.

Penyebab lain juga terjadi saat siswa kurang dapat membandingkan contoh positif dan negatif yang ada pada LKPD (indikator 5). Hal ini dikarenakan siswa tidak terbiasa dengan pembelajaran dengan membandingkan contoh yang salah dengan yang benar. Ada juga siswa yang dapat membandingkan dengan lisan tetapi merasa kesulitan saat diminta untuk menuliskannya pada LKPD. Dalam hal ini guru 
mencoba membantu siswa dengan memberikan contoh salah satu perbedaannya dan cara menuliskannya pada LKPD.

Pada tahap ketiga model pembelajaran concept attainment juga terlihat siswa kurang dapat menganalisis strategi-strategi berpikirnya untuk menyelesaikan beberapa soal yang diberikan. Hal ini dikarenakan pada tahap penyajian data dan identifikasi konsep siswa terbiasa dengan mengukur panjang sisi, besar sudut, dan panjang diagonal sehingga saat diterapkan pada soal siswa kembali mengukur dengan menggunakan penggaris dan busur tanpa memperhatikan apa yang diketahui pada soal. Dalam hal ini guru mengingatkan kepada siswa untuk memperhatikan apa yang diketahui dan ditanyakan pada soal yang ada.

Saat proses presentasi selesai dan guru meminta siswa lain untuk memberikan pendapat mengenai apa yang dipresentasikan, banyak siswa belum mampu menanggapi hasil presentasi temannya. Dalam hal ini guru memancing siswa untuk bertanya dengan temannya yang sedang melakukan presentasi.

Pada siklus II penerapan model pembelajaran concept attainment masih kesulitan saat membandingkan contoh positif dan negatif yang ada pada LKPD (indikator 5) sama seperti siklus I. Tetapi pada siklus II ini hanya beberapa siswa yang mengalami hal demikian.

Pada siklus I dan II terlihat belum ada peningkatan yang signifikan mengenai keaktifan siswa dalam mempresentasi hasil diskusi kelompok dan memberi tanggapan atas presentasi kelompok lain (indikator 10 dan 11). Hal ini dikarenakan siswa belum terbiasa dengan proses pembelajaran seperti ini.

Pada siklus III sudah terlihat peningkatan aktivitas sangat signifikan. Hal ini dikarenakan siswa sudah mulai terbiasa dengan model pembelajaran concept attainment yang diterapkan dan siswa sudah mulai aktif dalam proses presentasi dan menanggapi hasil presentasi kelompok lain.

Berdasarkan hasil tes akhir siklus I, II, dan III terlihat adanya peningkatan aktivitas belajar matematika siswa. Hal ini membuktikan teori menurut Uno (2017: 10) yang menyebutkan model pembelajaran concept attainment bertujuan membantu siswa untuk aktif dalam memahami suatu konsep pelajaran. Terlihat pada tiap siklusnya aktivitas belajar siswa meningkat hal ini dikarenakan model pembelajaran yang digunakan membuat siswa terlatih aktif dalam proses pembelajaran dan dapat menemukan konsep sendiri sehingga pelajaran lebih bermakna, pada akhirnya hasil belajar siswa dapat meningkat.

\section{PENUTUP}

\section{Simpulan}

Penerapan model pembelajaran concept attainment dapat meningkatkan aktivitas belajar siswa kelas VII SMP Negeri 1 Pondok Kelapa, yaitu dengan cara pembagian kelompok yang heterogen, diskusi kelompok, presentasi hasil diskusi kelompok, dan penyimpulan. Skor rata-rata pengamat aktivitas belajar siswa pada siklus I sebesar 27,875 (kategori cukup aktif), pada siklus II sebesar 36,75 (kategori aktif), dan pada siklus III sebesar 43,75 (kategori sangat aktif).

\section{Saran}

Berdasarkan hasil penelitian yang telah dilakukan oleh peneliti, maka saran yang dapat diberikan oleh peneliti adalah:

1. Mengoptimalkan waktu yang digunakan untuk pengerjaan LKPD concept attainment agar waktu pembelajaran tidak hanya habis digunakan untuk pengamatan membandingkan contoh positif dan negatif saja, hal ini dapat ditindaklanjuti salah satunya dengan memberi gambar bangun datar yang memiliki panjang sisi bilangan bulat sehingga siswa tidak kesulitan dalam mengukur dan membandingkan contoh yang diberikan.

2. Pembelajaran dengan menggunakan model pembelajaran concept attainment akan lebih efektif berlangsung jika mengkombinasikan alat peraga pada tahap penyajian data dan identifikasi konsep. 


\section{DAFTAR PUSTAKA}

Dahar, Ratna Wilis. (2011). Teori Belajar dan Pembelajaran.Jakarta: Erlangga.

Hamdani. (2011). Strategi Belajar Mengajar. Bandung: Pustaka Setia.

Huda, Miftahul. (2017). Model-Model Pengajaran dan Pembelajaran. Yogyakarta: Pustaka Belajar.

Joyce, Bruce, Marsha Weil dan Emily Calhoun. (2009). Models of Teaching (Model-Model Pengajaran). Yogyakarta: Pustaka Belajar.

Ridwan, Reno. (2013). Penerapan Model Pembelajaran Concept Attainment dalam Upaya Meningkatkan Aktivitas dan Hasil Belajar IPS Terpadu Siswa Kelas VII J SMP N 4 Bukittinggi. Skripsi tidak diterbitkan. Padang: Universitas Negeri Padang.
Sardiman. (2008). Interaksi dan Motivasi Belajar Mengajar. Jakarta: Raja Grafindo Persada.

Sudijono, Anas. (2011). Pengantar Evaluasi Pendidikan. Jakarta: Rajawali Pers.

Sudjana, Nana. (2016). Penilaian Hasil Proses Belajar Mengajar.Bandung: Rosdakarya.

Trianto. (2011). Panduan Lengkap Penelitian Tindakan Kelas. Jakarta: Prestasi Pustaka.

Uno, Hamzah B. (2017). Model Pembelajaran Menciptakan Proses Belajar Mengajar yang Kreatif dan Efektif. Jakarta: Bumi Aksara. 